\title{
Review
}

\section{Photoreceptor guanylate cyclase variants: cGMP production under control}

\author{
Izabela Sokal $^{1}$, Andrei Alekseev ${ }^{1}$ and Krzysztof Palczewski ${ }^{1,2,3 凶}$ \\ Departments of ${ }^{1}$ Ophthalmology, ${ }^{2}$ Pharmacology, and ${ }^{3}$ Chemistry, University of Washington, \\ Seattle, WA 98195, U.S.A.
}

Received: 20 August, 2003; revised: 11 October, 2003; accepted: 14 October, 2003 Key words: retina, photoreceptor cells, guanylate cyclase, rhodopsin, $\mathrm{Ca}^{2+}$-binding proteins, guanylate
cyclase-activating protein

\begin{abstract}
Changes in the $\mathrm{Ca}^{2+}$ concentration are thought to affect many processes, including signal transduction in a vast number of biological systems. However, only in few cases the molecular mechanisms by which $\mathrm{Ca}^{2+}$ mediates its action are as well understood as in phototransduction. In dark-adapted photoreceptor cells, the equilibrium level of cGMP is maintained by two opposing activities, such as phosphodiesterase (PDE) and guanylate cyclase (GC). Upon absorption of photons, rhodopsin-G-protein-mediated activation of PDE leads to a transient decrease in [cGMP] and subsequently to lowering of $\left[\mathrm{Ca}^{2+}\right]$. In turn, lower $\left[\mathrm{Ca}^{2+}\right]$ increases net production of cGMP by stimulation of GC until dark conditions are re-established. This activation of GC is mediated by $\mathrm{Ca}^{2+}$-free forms of $\mathrm{Ca}^{2+}$-binding proteins termed GC-activating proteins (GCAPs). The last decade brought the molecular identification of GCs and GCAPs in the visual system. Recent efforts have been directed toward understanding the properties of GC at the physiological and structural levels. Here, we summarize the recent progress and present a list of topics of ongoing research.
\end{abstract}

\footnotetext{
${ }^{\star}$ This research was supported by NIH grants EY09339, a grant from Research to Prevent Blindness, Inc. (RPB) to the Department of Ophthalmology at the University of Washington, and a grant from the E.K. Bishop Foundation. K.P. is a RPB Senior Investigator.

${ }^{\bowtie}$ Krzysztof Palczewski, Department of Ophthalmology, Box 356485, University of Washington, Seattle, WA 98195-6485 U.S.A.; phone: (206) 543 9074; fax: (206) 2216784 fax: 356 485;

e-mail: palczews@u.washington.edu

Abbreviations: AC, adenylate cyclase; ANP, atrial natriuretic peptide; CaM, calmodulin; $\mathrm{CD}$, catalytic domain; DD, dimerization domain; ECD, extracellular domain; GC, guanylate cyclase; GCAP, guanylate cyclase-activating protein; Gt, rod photoreceptor G protein; ICD, intracellular domain; KHD, kinase-homology domain; Meta II (or R*), metarhodopsin II (photoactivated rhodopsin); NPR, natriuretic peptide receptor; PDB, Protein Data Bank; RMSD, root-mean-square deviation; PDE, phosphodiesterase; ROS, rod outer segments; STa, heat-stable enterotoxin; TM, transmembrane region.
} 
Among cyclic nucleotides, the utilization of cGMP is not understoodas well as that of cAMP. cGMP activates cGMP-dependent protein kinases, opens cGMP-gated cation channels, or regulates phosphodiesterases (PDEs) (Wong \& Garbers, 1992). Guanylate cyclases (GCs) are enzymes that catalyze the conversion of GTP to cGMP, while specific subtypes of PDEs are involved in the hydrolysis of cGMP to GMP (Soderling \& Beavo, 2000). GMP is recycled back to GTP by guanylate kinase and nucleoside diphosphokinase.
GCs come in two varieties: soluble and membrane-bound GCs with multiple isoenzymes of both forms being expressed ubiquitously (Drewett \& Garbers, 1994; Kobialka \& Gorczyca, 2000; Gorczyca et al., 2003). The membrane-bound GCs display similar topologies and belong to a family of single transmembrane-spanning signaling receptors (Singh et al., 1988) (Fig. 1A). They are composed of extracellular domain (ECD), single-spanning transmembrane region (TM), and intracellular domain (ICD) which is fur-
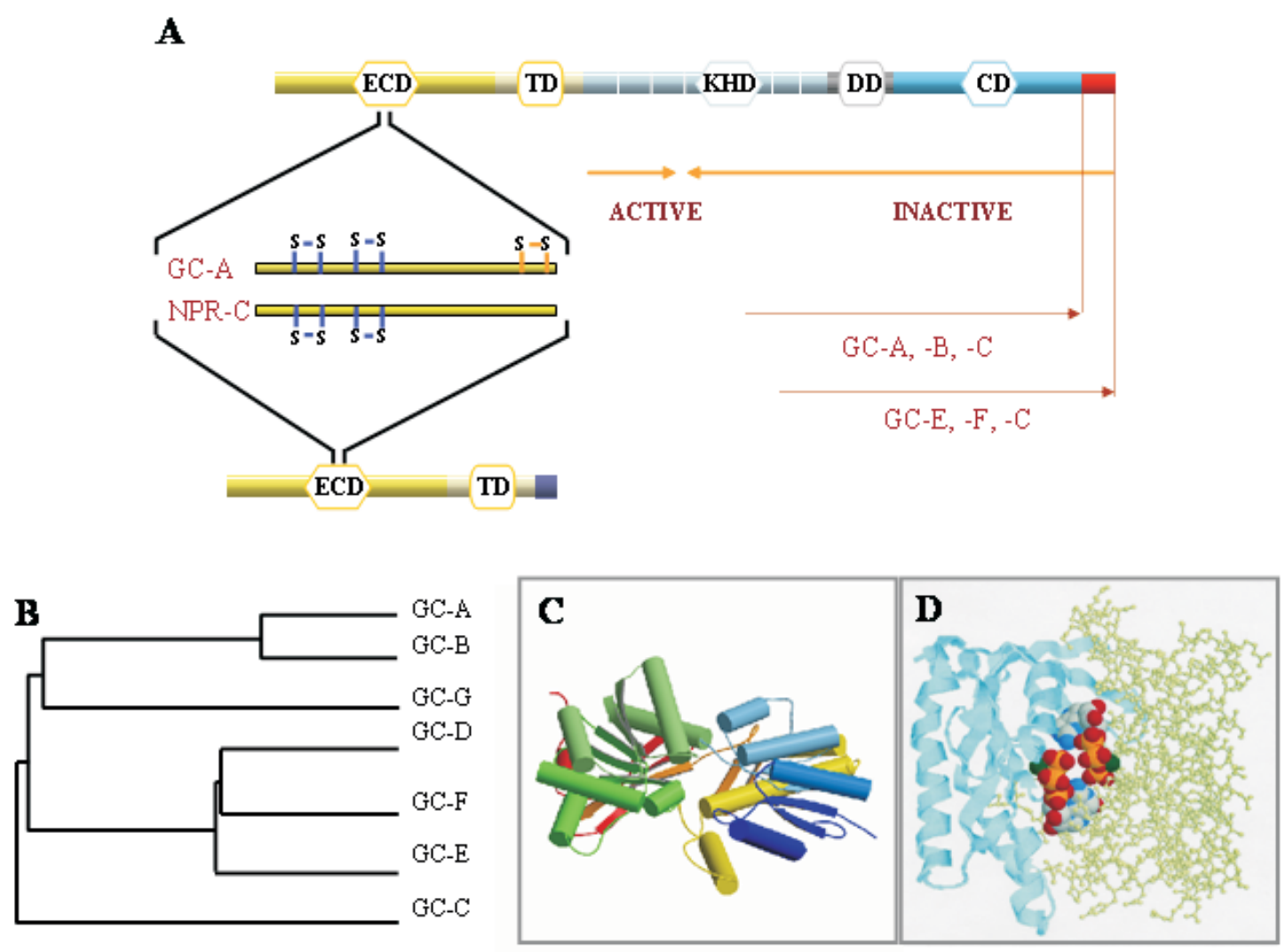

Figure 1. Guanylate cyclases and natriuretic peptide receptor $\mathrm{C}$.

A. Topological representation of GC domains and NPR-C. ECD (extracellular domain), TM (transmembrane domain), KHD (kinase-homology domain), DD (dimerization domain), and CD (catalytic domain) are indicated. Blue lines indicates the positions of disulfide bridges as inferred from crystallographic studies in the ECD, and orange lines mark one disulfide bridge identified based on biochemical studies. Orange arrows mark the minimal truncated GC-E sequence needed for GC activity. The unique C-terminal fragment present in GC-E, - $\mathrm{F}$ and -C is shown as a red square. B. A phylogenetic tree calculated from the amino-acid sequences of mammalian GC is represented as the function of similarity between GCs. Analysis was performed using ClustalW program. C. Three-dimensional model of the ECD of NPR-C receptor (PDB ID: 1JDN) (He et al., 2001). Arrows represent $\beta$-strands, cylinders are $\alpha$-helices. The figure was drawn by using Molscript (Kraulis, 1991) and Roster3d (Merritt \& Bacon, 1997) programs. D. Model of the CD from GC-E (1AWL) (Tucker et al., 1998). Two subunits are shown in two different representation styles and two GTP molecules are shown in the default atom colors. Note that the active site is composed of residues from both subunits, and two active sites are present for the dimer. The figure was generated using the RasMol (Sayle \& Milner-White, 1995). 
ther subdivided into kinase-homology domain (KHD) and catalytic domain (CD) (Garbers, 1989). In mammals, the family of membrane-bound GCs includes receptors for natriuretic peptides (NPRs), GC-A (NPR-A) and GC-B (NPR-B) (Garbers, 1989) (Fig. 1B). An intestinal peptide-binding receptor, GC-C belongs to the second group of the membrane-bound GCs (Fig. 1B) and is also the receptor for heat stable enterotoxin (STa). Four other GCs, GC-D (Fulle et al., 1995; Juilfs et al., 1997), GC-E, GC-F (discussed below) and GC-G (Schulz et al., 1998), expressed in sensory and peripheral tissues, are considered orphan receptors because they display the membrane-bound GC topology, but the putative ligand for these cyclases has not been identified (Fig. 1B). This small number of GCs is in contrast with more than 29 GCs identified in Caenorhabditis elegans (Baude et al., 1997; Marchese et al., 1998). It was speculated that the large number of GCs could complement $\mathrm{G}$ protein-coupled receptors (GPCRs) in the olfaction system (Yu et al., 1997). The interplay between olfactory GCs and olfactory GPCRs is unclear.

Phototransduction in the rod photoreceptor cell employs cGMP as a second messenger that couples absorption of light to changes in conductivity of cation channels in the plasma membrane (Yau \& Baylor, 1989; Polans et al., 1996; Baylor \& Burns, 1998; Arshavsky et al., 2002). Phototransduction events are initiated when a photon strikes rhodopsin causing photoisomerization of the chromophore 11-cis-retinal (Okada et al., 2001; Filipek et al., 2003). The photoisomerized chromophore induces a sequence of conformational changes in rhodopsin that culminates in the formation of Meta II, which catalyses the exchange of GDP to GTP in hundreds of Gt molecules (Leskov et al., 2000; Heck \& Hofmann, 2001) before it is phosphorylated (Kuhn \& Dreyer, 1972; Bownds \& Brodie, 1975; Frank \& Buzney, 1975; Miller et al., 1975; Kuhn \& Bader, 1976; Palczewski, 1997; Palczewski \& Benovic, 1991; Maeda et al., 2003). Continu- ous Gt activation is prevented by the binding of arrestin to phosphorylated Meta II (Kuhn et al., 1984; Wilden et al., 1986) (reviewed by Okada et al., 2001; Filipek et al., 2003). Phototransduction proceeds with the GTP- $\alpha$-subunit of Gt activating PDE (Stryer, 1983), and cGMP is hydrolyzed faster than it is replenished by GC. GC-E and GC-F were proposed to be involved in phototransduction. GC-E (also known as GC1 or retGC1) was cloned in 1992 (Shyjan et al., 1992). A frameshift error was corrected soon after (Lowe et al., 1995). GC-F (GC2 or retGC2) was cloned from retinal cDNA libraries (Lowe et al., 1995; Yang et al., 1995). Both isoenzymes are expressed in rod and cone photoreceptor cells (Dizhoor et al., 1994; Yang \& Garbers, 1997; Duda et al., 2002; Imanishi et al., 2002). GC-E was also found in the pineal gland, an organ developmentally related to the retina (Venkataraman et al., 2000).

Reduced concentrations of cGMP result in the closing of the plasma membrane cGMP-gated cation channels (Fesenko et al., 1985), and hyperpolarization of the cell. The $\mathrm{Na}^{+} / \mathrm{Ca}^{2+}-\mathrm{K}^{+}$exchanger (NCKX) removes $\mathrm{Ca}^{2+}$ from ROS, leading to lower levels of $\left[\mathrm{Ca}^{2+}\right]$ that in turn trigger a feedback mechanism of the enhancing photoreceptor GC activity through $\mathrm{Ca}^{2+}$-binding protein GCAPs and restoring the dark levels of cGMP (reviewed in Polans et al., 1996) (Fig. 2). The molecular identity of GCAP, whose presence was suspected from previous studies (Lolley \& Racz, 1982; Koch \& Stryer, 1988), was advanced in our laboratory by the original work of Dr. W. Gorczyca, who isolated the first form of the activator from photoreceptor cells (Gorczyca et al., 1994). The second GCAP2, was isolated independently by Gorczyca and Dizhoor (Dizhoor et al., 1995; Gorczyca et al., 1995), and the GCAP3 was cloned by us (Haeseleer et al., 1999). Importantly, our progress on studies of the GC regulation also benefited from a close collaboration of our laboratory with Dr. W. Baehr (University of Utah, U.S.A.). 


\section{STRUCTURE OF PHOTORECEPTOR GUANYLATE CYCLASES AND THEIR RELATIONSHIP TO OTHER FAMILY MEMBERS}

The basic topologies of orphan receptors consist of about 500-amino acid-long ECD, 23-residue hydrophobic TM and about 500-600 amino acid-long ICD that contains the signature domains of membrane GCs (KHD and CD) (Singh et al., 1988; Drewett \& Garbers, 1994; Potter \& Hunter, 2001) (Figs. $1 \mathrm{~A}$ and 3 ).

\section{Signal peptide and extracellular domain (ECD)}

All GCs contain a signal peptide sequence that targets the protein to the membranes. The N-terminal analysis of isolated GC-E reveals that the first 56 amino-acid residues are removed by signal peptide peptidase (Margulis et al., 1993).

The ECDs are weakly related among the GC family $(32-38 \%)$. The high-resolution structures of the ECDs were determined for GC-A (van den Akker et al., 2000) (PDB ID: 1DP4) (Fig. 1C) and natriuretic "clearance" receptor

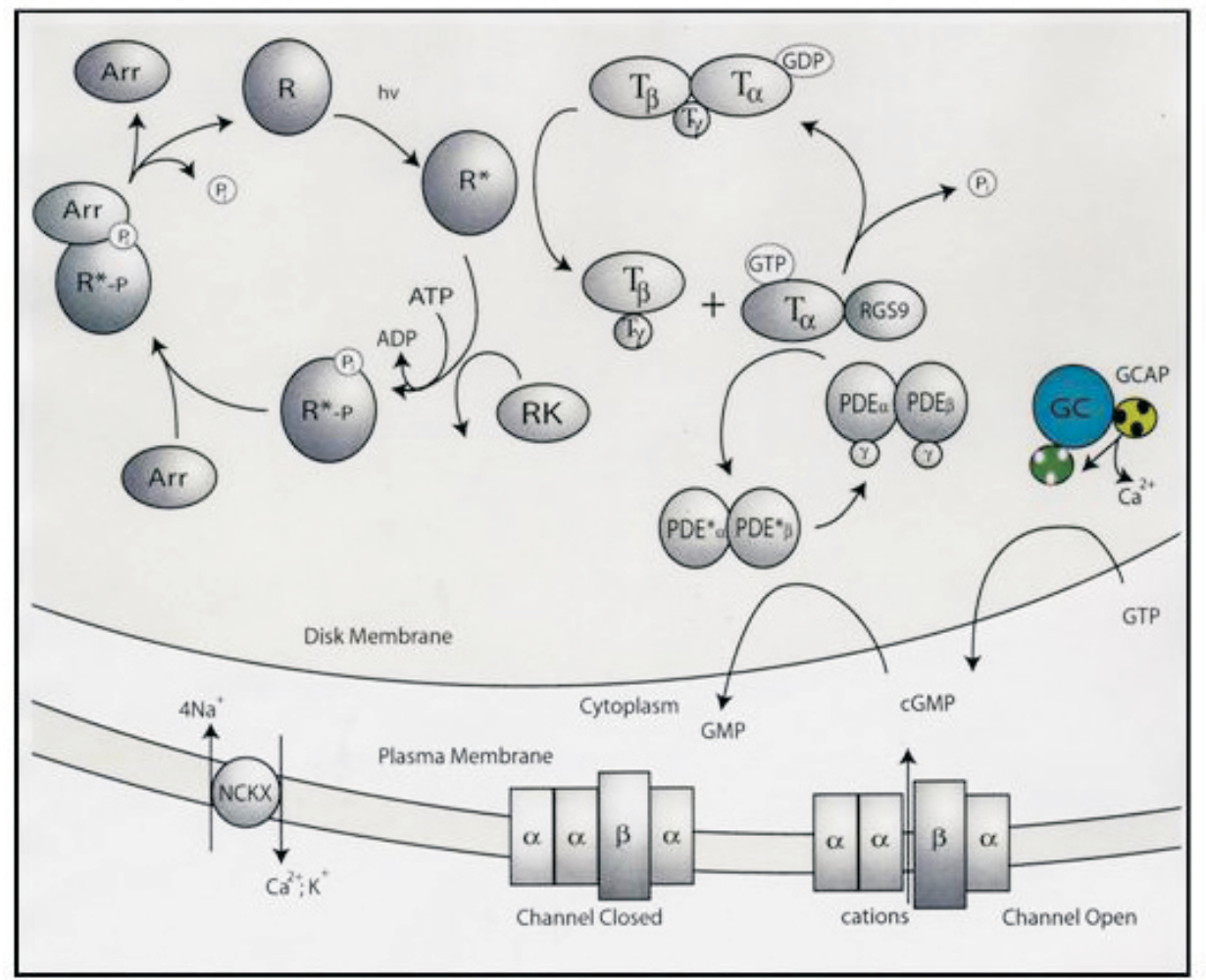

Figure 2. Phototransduction.

Absorption of light by rhodopsin (R) leads to transient conformation change and formation of the active form of this receptor, Meta II (or $\mathrm{R}^{*}$ ). In the dark, trimeric G-protein transducin (T) has bound GDP, which is replaced by GTP upon interaction with Meta II, and in turn transducin splits into $\alpha$-subunit-GTP and $\beta \gamma$-subunits. The $\alpha$-subunit-GTP activates PDE, which hydrolyses cGMP. Lowering [cGMP] causes closure of the cGMP-gated cation channel and hyperpolarization of the plasma membrane. Lower conductance of the cation through the channel also lowers $\left[\mathrm{Ca}^{2+}\right]$, because the ion is removed continuously by the $\mathrm{Na}^{+} / \mathrm{Ca}^{2+}-\mathrm{K}^{+}$exchanger. Dissociation of $\mathrm{Ca}^{2+}$ from GCAP1 leads to a conformation change in this $\mathrm{Ca}^{2+}$-binding protein and activation of photoreceptors GCs (GC-GCAP shown in colors) and enhanced synthesis of cGMP. The restoration of the dark conditions requires inactivation of Meta II, hydrolysis of GTP by $\alpha$-subunit of transducin, and inactivation of PDE (for details see Palczewski et al., 2000; Polans et al., 1996). The RGS9 complex consists of RGS9 protein, $\beta 5$-subunit of G-protein and a membrane anchor, R9AP protein. Abbreviations used: R, rhodopsin; R*, Meta II (photoactivated rhodopsin); RGS, regulator of G-protein signaling; RK, rhodopsin kinase; Arr, arrestin; T, transducin; $\mathrm{NCKX} \mathrm{Na}^{+} / \mathrm{Ca}^{2+}-\mathrm{K}^{+}$ exchanger. 
(NPR-C) (He et al., 2001) (PDB ID: 1JDN). The structure of the ECD of GC-A resembles an ancient class of proteins termed the bacterial type I periplasmic solute-binding proteins that bind small molecules between two structurally independent sub-domains. The ECD forms a dimer, and each monomer is dumbbell-shaped, with each domain consisting of a central sheet surrounded by helices. The arrangement of the monomers of ECD in the crystal is different than the model generated from the biochemical studies for GC-A (Rondeau et al., 1995; De Lean et al., 2003) and perhaps induced by the crystallization conditions. The ECD also contains a $\mathrm{Cl}^{-}$ion that is essential for high affinity binding of ANP (Misono, 2000). The second high-resolution structure of the ECD was determined for the NPR-C with and without ligand (He et al., 2001). The RMSD between ECDs of GC-A and NPR-C is about $2.5 \AA$. In the ligand-bound complex, a single natriuretic peptide molecule is bound in the interface of the NPR-C dimer, in agreement with the biochemical data. Hormone binding induces a $20 \AA$ closure between the membrane-proximal domains of the dimer, suggesting conformation rearrangement with the ECD which induces changes that are propagated into the intracellular domain; thus ultimately enhanced the GC activity. From both structures, two disulfide bridges are demonstrated in identical positions (Fig. 3); however, the two Asn glycosylation sites are not conserved (Fig. 3), suggesting that these modifications are involved in the overall stability of the proteins rather than their having any functional significance. These modifications may also protect the receptor against proteolysis in the native tissue or assist folding by interacting with the ER chaperons like calnexin and calreticulin. As both crystallized fragments of the enzymes are produced in the heterologous expression systems, we need proofs that these sites are also utilized by the GCs in the native tissues. The NPR-C structure also contains two $\mathrm{Cl}^{-}$-binding sites which are believed to be important for the integral stability of the protein (He et al., 2001), and not for ligand binding, as the position of this anion is distal from the ligand binding site and unchanged in the ligand-bound and free forms of the receptor.

No extracellular ligands have been found for GC-D, GC-E or GC-F, and these cyclases do not respond to any peptides that regulate activity of NPRs (Shyjan et al., 1992; Yang et al., 1995). Sequence analysis of the ECDs of orphan receptors suggests that they may fold into a somewhat different structure than those of GC-A and NPR-C. The ECD of GC-E, GC-F and GC-D isoforms contain conserved Cys residues with high homology to other membrane-bound GCs (Fulle et al., 1995), but the proven disulfide bridges are not conserved (Fig. 3). There is only the weak conservation throughout these ECDs, mostly among a few hydrophobic residues. Based on the sequence analysis of the ECDs, one N-linked glycosylation sites was predicted in GC-E, while more than one were in GC-D, but not in GC-F (Fulle et al., 1995; Yang et al., 1995). N-linked glycosylation was proven experimentally using bovine ROS as a source of GC-E and appears to be different than that of GC-A (Koch et al., 1994). Additional studies are needed in the analysis of the glycosylation site and the composition of the sugar moieties attached to photoreceptor GCs.

An important issue for phototransduction is the question of putative ligands of GC-E and GC-F. The ligand would exert another level of regulation of GC that is important during dark- and light-adaptation (Fain et al., 2001). The ligand for GC-E or GC-F should be diffusible; however, ECDs of these GCs are, in large part, sequestered in the lumen of disks of rod photoreceptor cells, or inaccessible within highly folded cone outer segment disks. If a ligand did exist, on the time scale of visual processes, renewal and re-synthesis of the ligand would be an unlikely process. However, the ligand could be a permanent subunit of the GC-E or GC-F. Because the GC-E and 
ECD

hGC-A : . . . . . . . . . . . . . . . NPGPRRPAGSRLRLLLLILLLPPLILLLRGSHAG . . . . . . NL :

hGC-B : $\ldots \ldots \ldots$.

hGC-C : -.......................... IGC-D : MAGLQQGCHPEGQDWTAPHWKTCRAIPGPRGLTVRHLRTVSSI SVFSVVFWGVLLWADSLSLPAWARET hGC-E : - - -MTACARRAGGLPDP - - - - G CGPAWWAPSLPRLPRA PRLPLILLLLLLQPPALS - - - - - AV : hGC-F : -MFLGLGRF SRLVLWFAAFR - - - KLLGHHGLAS - - AKFLWC CLLSVI SLPQQVWT - - - - - - - - LP :

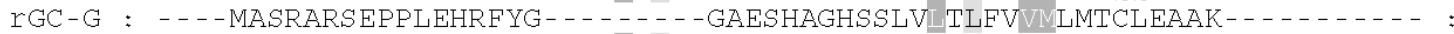
hNPR-C: - - - - MPSLLVLTF SPCVLLGWALIAGGTGGGGVGGGGGGAGIGGGRQEREALPPQK - - - - - - - - :

hGC-A : TVAVVIPLANTSYPWWWARVPAVETATAQVIKARPDLLPGWTVRTVLGSSE-NALGVCSDTAAPLAAVD: 103 hGC-B : TLAVVL PEHNLSYAWAWPRVGPAVALAVEA GR- - -ALP- - -VDLRFVSS - -ELEGA SEYLAPLSAVD: 86 rGC-C : FTIGVLGWDCDPI AQALPSM TQIAVDR NQDASLLLGSQLDFKILPT- - - -G DTPHALATF IA: 132 hGC-D : ISVLMIGNSAFAEPLKNLEDAVNEG EIVRGRLQNAGLNVTVNATFMYSDG-LIHNSGDCRSSTCEGID： 104 hGC-E : FTVGVL GPWACDPI SRARPDLAARIAAAR NRDPGLAGGPRFEVALLPE- - - -P RTPGSLGAVSS: 116 hGC-F : YKIGVVGPWACDSL SKALPEVAARIAIERINRDP SFDLSYSFEYVILNE- - - - -DCQTSRALSSFIS: 115 rGC-G : LTVGFHAPWNI SHP EVQRLGAGLQIAVDK NSEPVGPGNLSWEFTYTNA - - - - -T NAKESLAAFID : 108 hNPR-C: IEVLVLPQDD SYLESLTRVRPAIEYARS EGNGTGRRLLPPGTRFOVAYEDSDCGNRALFSLVDRVA: 121

hGC-A : LKWEHNPAVFLG GCVYAAAPVGRFTAHWVPLLTAGAPALGFGVK-DEYALTTRAGPSYAKLGDFVAA : 171 hGC-B : LKLYHDPDLLI hGC-C : LLRKISNAQR IGC-D : HRN- -TVAAF hGC-E: ALA--RVSGL hGC-F : HHQ--MASGE
rGC-G : QVQREHISVI hNPR-C: AARGAKPDLILG PVEYAAAPVARLASHWDLPM GCVYPAASVARFASHWRLP CVLIGP SCTYSTFOMYLDTET SYPMI SA GSFGISCDYKTLVRGPSAPKLGEFVVT VNPGYCPAAALLAQG WKSLFSWACGAP - - -EGG- - - GALVPTLPSMADVLL VNPAACRPAELLAEEAGIAI TNPGYCEAASLLGNSWDDKG ACPEAAEVIGLLASEWDIP SWACVNY - - - ELDNKISYPTFSRTLPSPIRVLVT : 178 FDFVGQMT - - - ALEDHFWCDTCVTLVPPKQEIGTV : 173

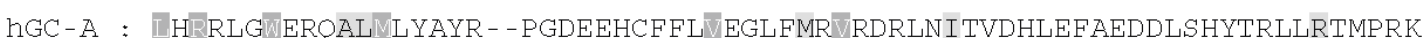
hGC-B : ¿HGHFNWTARAALLYLDA--RTDDRPHYFT_EGVFEA_QG-SNLSVQHQVYARE-PGGPEQATHFIRAN hGC-C : FW TNDLPFKTYSWSTSYVYKNGTETEDCFWYLNALEASVSYFSHELGFKVVLRQDKEFQDILMDHNRK IGC-D : VMRHFGWARLAI S SHQD I WVTTAQQLATAFRAHGLP I GL ITSLGPGEK-GATEVCKQLHSVHGLKIVV hGC-E : LRAFG ARVALVTAPQDLWVEAGRSLSTA RARGLPVASVTSMEPLDLSGAREALRKVRDGPRVTAVI hGC-F : VMKYFONAHAGVISSDEDI WVHTANRVASAI RSHGLPVGVVLTTGODSO-SMRKALORIHOADRIRI I I rGC-G : IRESLQ LGWEY GVFGGSSAGSSWGEVNE WKAVEDELQLHFTITARVRYSSGHSDLLQEGLRSMSSV hNPR-C: ¿FRHHHWSRALVYSDDK--- - LERNCYFT EG-VHEV FQEEGLHTS I YSFDETKDLDLED IVRNIQAS
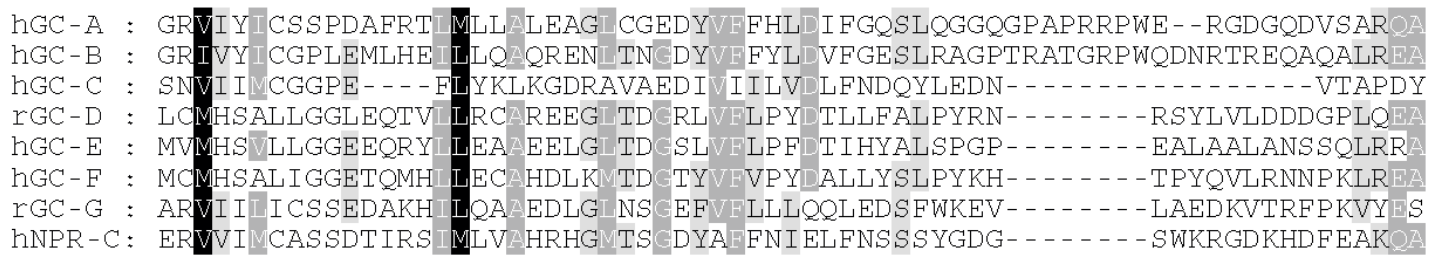
(1) .

hGC-A : FQAAKIITYKDPDNPEYLEFLKQLKHLAYEQFNFTMEDGLVNTIPASFHDGLIYIQAVTETIIHGGTV : 374 hGC-B : FQTVLVIYREPPNPEYQEFQNRLLIRAREDFGVELGPSLMNLIAGCFYDGILYAEVLNETIQEGGTR: 358 hGC-C : MKNVLVITLSPGNSLLNSSFSRNLSPTKR - . . . . - - DFALAYLNGILIFGHMLKIFI ENGENI : 346 YGC-D : YDAVLTISLDTSPES-- -HAFTATKMRGG--AAANLGPEQVIPLFGTIYDAVILAHALNHSETHGTG- : 382 hGC-E : HDAVLTTRHCPSEGSVLDSLRRAQERRE--LPSDLNLQQVSPLFGTIYDAVFILARGVAEARAAAGGR : 371 hGC-F : YDAVLTIVES-QEKTFYQAFTEAAARGE--IPEKLEFDQVSPLFGTIYNSIYFIAQAMNNANKENGQ- : 372 rGC-G : VFLIAPSTYGGSAGDDDFRKQVYQRLRRPPFQSSISSEDQVIPYSAYLHDAL YIAQTVEEM KAEKDF : 372 hNPR-C: YSSLQTVILLRTVKPEFEKFSMEVKSSVE--KQGLNMEDYVNMFVEGFHDAI YVLALHEVLRAGYSK : 382

hGC-A : -TDGENITQR-MWNRSFQGVTGY KIDSSGDRETDFSLWDM-DPEN AFRVVLNYNGTSQELVAVSGRK : 440 hGC-B : -EDGLRIVEK-MOGRRYH hGC-C : TTPKFAHAFR - -NTTFEGYDCPVT DKNNDRETDEV IGC-D : - LSGAH GNH-IRALDVAGFSQRIRIDGKGRRLPQVV hGC-E : WVSGAAVARH-IRDAQVPGFC - - -DLGGDEEPP hGC-F : -AGAAS VQH - SRNMQFHGFNQL RTD SNGNGISE IGC-G : RDGRQLISTLRADQVTLQGIT PVL DAQ KRHMD hNPR-C: KDGGKIIQQT- -WNRTFEGIACQVSIDANGDRYGDF WAMGDLDS DFOPAAHYSG - AEKOIWWTGRP LYTSVDTKKYKVLLTYDTHVNKTYPVDMSPT LDTN - -GE SQLVPTHILDVSTQQVQPLGTA LDTD - AA DRLFATYMLDPARGSFLSAGTR LDTN - - LKEWELHSTYTVDMEMELLRFGGTP YALQKSGN SRFLPFLHYDSFQKVIRPWRDD AMTDVEA TOEVIGDYFGKEGRFEMRPNVK

hGC-A : INWPL--GYPPPDIPKCGEDNEDPACNQ--- - -DHISTRKMQE : 477 hGC-B : IPWVK--GAPP SDNPPCAFDLDDPSCDK-...-TPISTRKLM E : 461 hGC-C : FTWKN--SKLPNDITGRG-...........MLRIYRKDY : 438 IGC-D : VHFP--GSPPAHDAS WEDPNTLCIRG-..--VQRIPLGLQQR : 485 hGC-E : MHFPR-G SAPGPDPS WEDPNNICGGG- - - -LEYVRHRLLHM : 472 hGC-F : IHEP--G RPPRADAKCWFAEGKICHGG-...-IDPARRRINKIQ : 475 IGC-G : LNASGPHGSHPEYKPDCGEHEDLCRTKPPTGAGMTLMDWRLRGKVQ : 487 hNPR-C: YPWGPLKLRIDENRIVEHTNSSPCKSSG-----FFGLRKKYRIT : 488

Figure 3. Legend to the figure on the page 1082. 


\section{TM}

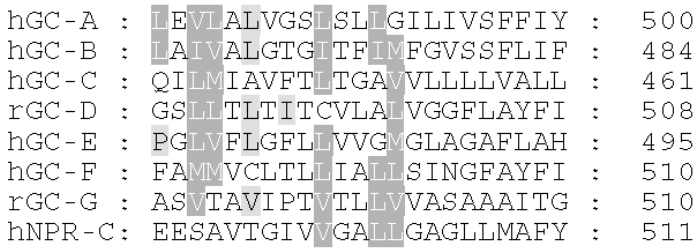

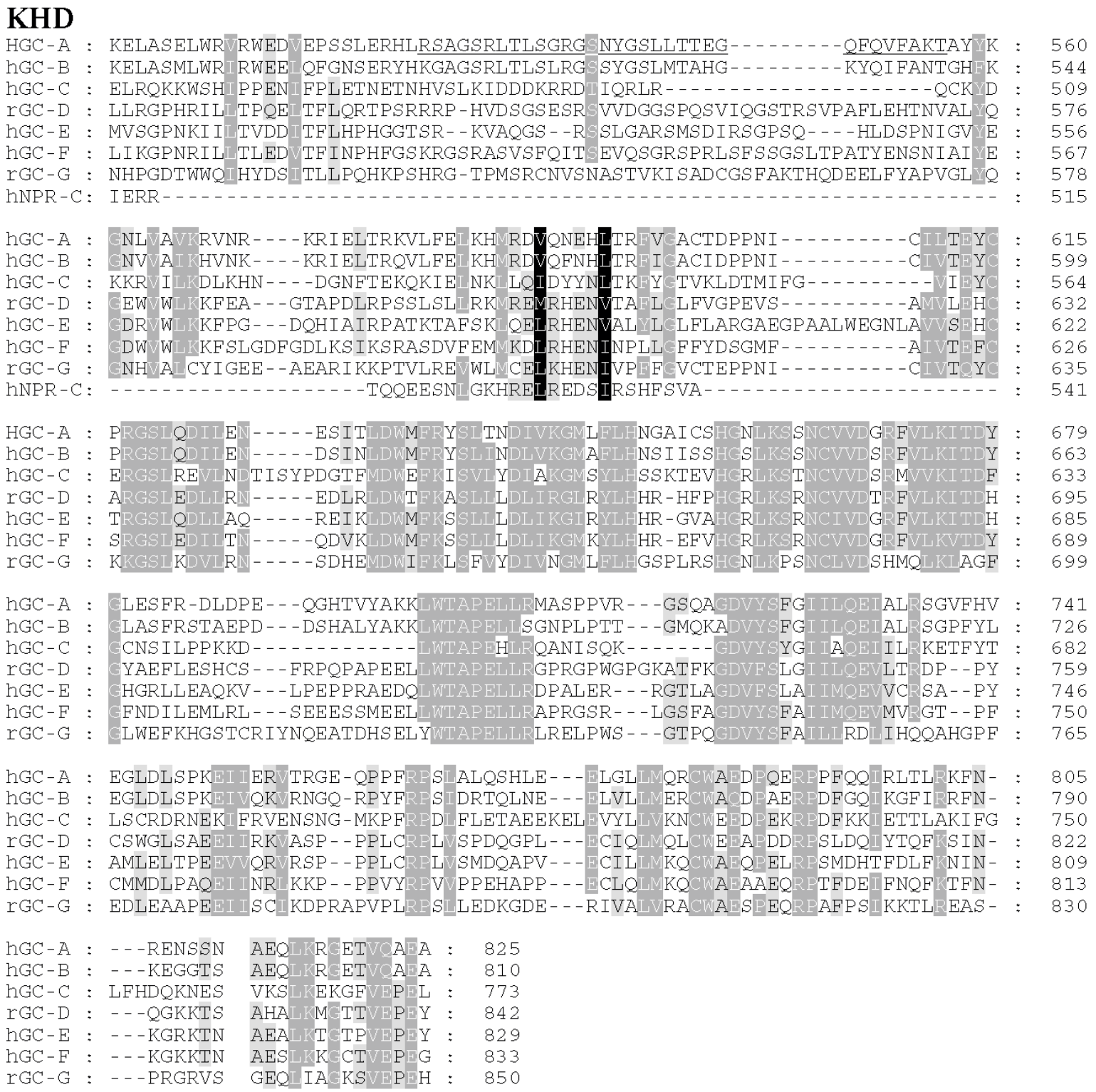

Figure 3. Legend to the figure on the page 1082.

GC-F fragments lacking the ECD are highly active in the presence of GCAPs (Duda et al., 1996; Laura et al., 1996; Sokal et al., 2002), this putative ligand is not essential for GC activity.
Exposure of membrane preparations containing GC-C to its ligand prior to addition of GTP resulted in dramatic inactivation and desensitization of the enzyme. GC-C inactivation could be a consequence of the 


\section{DD}

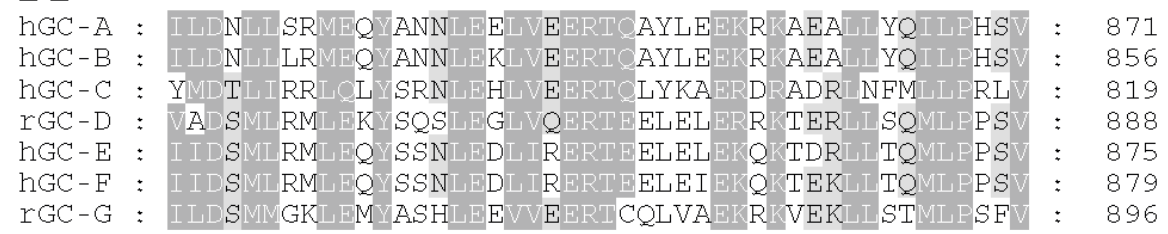

\section{CD}
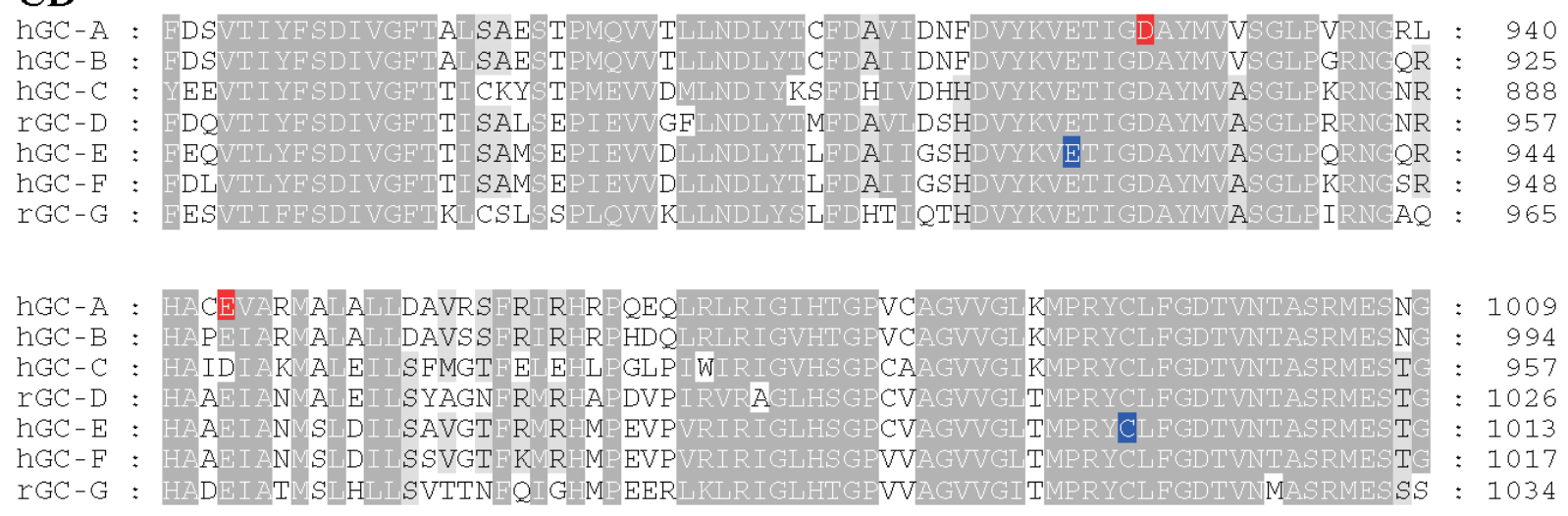

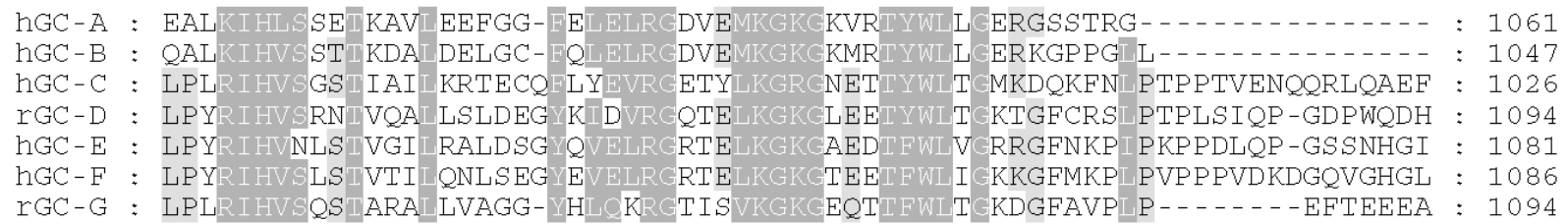

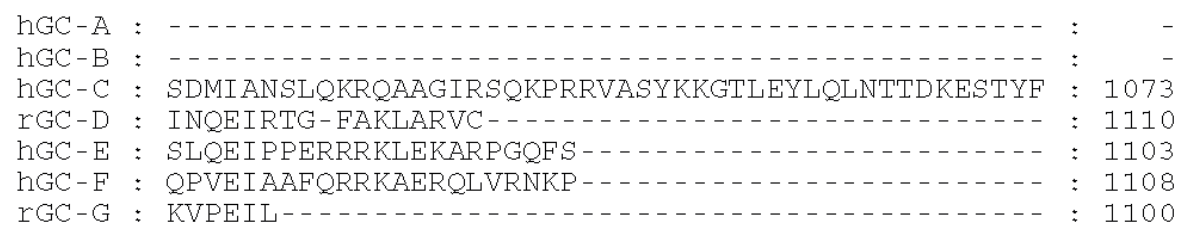

Figure 3. Sequence alignment of membrane-bound guanylate cyclases.

Residues that are 80-100\% identical or highly homologous are in white letters on the black background, residues that are $60-80 \%$ homologous are in white letters on the gray background and residues that are $40-60 \%$ homologous on the gray background. For GC-F, the first 56 amino-acid residues (bovine) is the cleaved signal peptide. The cleavage site is showed in bold font and underlined letter (Margulis et al., 1993). Two residues (marked on the blue background) in the catalytic site when mutated from E925K and C995D are sufficient to alter the nucleotide specificity from GTP to ATP (Tucker et al., 1998). The highly phosphorylated region in GC-A within KHD is underlined. Note that this region is poorly conserved among photoreceptors GC. In red are residues that lead to full inactivation of GC-A (D to A) or hyperactivity (E to A) (Thompson \& Garbers, 1995). The sequences were downloaded from the ExPASy Molecular Biology Server (Swiss Protein Data). 
conformational alterations induced by ligand binding (Bakre et al., 2000). The nature of this desensitization and its general usage among all sensory GCs requires more experimental evidence.

\section{Transmembrane domain (TM)}

The function of the transmembrane segment of GCs is to transmit the signal from the ligand-binding site in the ECD to the ICD. This portion of the receptors allows a single passage through the membrane bilayer. The $\alpha$-helix in the TM creates a rigid, hydrophobic region, which slips into membrane lipids. The GC-A and GC-C fragments containing ECD and TM were still capable of forming dimers (Chinkers \& Wilson, 1992), suggesting that in addition to ICD, ECD are also in the dimeric form. The mechanism by which receptors with a single TM transduce extracellular signals into intracellular conformation changes is still unknown. However, based on the differences between the crystal structure of the ligand-bound and ligand-free ECD of NPR-C, the C-terminal region of this domain undergoes conformational changes ( $\mathrm{He}$ et al., 2001). Such remodeling of the ECD would affect the transmembrane organization and induce changes within the ICD. A soluble GC-E mutant lacking the ECD and TM showed typical $\mathrm{Ca}^{2+}$-dependent stimulation by GCAP that was further enhanced by ATP (Sokal et al., 2002). These in vitro experiments demonstrate that the TM is not essential for the activity.

\section{Kinase-homology domain (KHD)}

To attain maximal GC activity, GC-A requires the natriuretic peptide, and ATP or a non-hydrolizable ATP analog to relieve the CD inhibition (Chinkers \& Garbers, 1989). This observation can be reconciled with the fact that GCs, as is true for most single-transmembrane spanning receptors, contain the ATP-binding domain homologous to protein kinases termed KHD. For example, mutations in GC-B within the Gly motif (GxxxG) of the KHD, which is critical for the formation of the ATP-binding pocket, decreased hormone dependent activity (Potter, 1998). Similar to other membrane-bound GCs, the ICDs of the sensory GCs also contain the KHD. Comparable motifs, $\mathrm{G}^{617}{ }_{\mathrm{xxxG}}{ }^{621}, \mathrm{G}^{502} \mathrm{xxx}$ $\mathrm{G}^{506}$, and $\mathrm{G}^{471} \mathrm{xxxG}^{475}$ are present in GC-D, GC-E and GC-F, respectively (Fig. 3) (Kobialka \& Gorczyca, 2000).

The aligned sequence of the KHD with Ser/Thr kinases and Tyr kinases shows that 24 of the 33 highly conserved amino acids, important for proper structure and function (Sefton, 1989), are present in the photoreceptor KHDs. The stimulating effect of ATP could suggest that GC-E is phosphorylated; however, the activation by non-hydrolyzable ATP analogs excludes this possibility (Gorczyca et al., 1994). In contrast, Aparicio and Applebury (1996) provided biochemical evidence that a member of the membrane receptor GC family (GC-E) possesses protein kinase activity. The authors suggested the existence of a single ATP-binding site within the KHD that both stimulates GC activity and catalyzes the transfer of the phosphate group in the $\mathrm{Mg}^{2+}$-dependent manner. The substrate for the phosphorylation was the cyclase itself (autophosphorylation) or some exogenous substrates. This kinase activity had properties distinct from other Ser/Thr protein kinases identified in ROS, including protein kinase $\mathrm{A}$, protein kinase $\mathrm{C}$, and rhodopsin kinase. Comparison of the sequence of GC-E with sequences of members of the protein kinase family shows that most of the amino acids essential for ATP binding and kinase activity are conserved in the KHD of GC-E. A notable exception is Asp166 residue which is proposed to be a catalytic base for the transfer of the phosphate group in protein kinases (Sefton, 1989). This amino-acid residue is replaced in all membrane-bound GCs by Ser, Arg or Asn, and suggests that GCs may not display kinase activity. Therefore, protein 
kinase activity of GC-E remains an open question.

\section{Dimerization domain (DD)}

A short region between the KHD and CD has been proposed to contribute to ligand-independent dimerization of GC-A (Wilson \& Chinkers, 1995). It appears that the DD is also necessary for GC activity based on deletion mutagenesis (Wilson \& Chinkers, 1995). However, the CD fragments of GC-A form a homodimers that are enzymatically active (Thorpe et al., 1991). Because the mechanism of the GC catalyzed reaction requires two subunits (reviewed by Hurley, 1998), in addition to the ECD, KHD, TM and $\mathrm{DD}, \mathrm{CD}$ also contributes to the GC oligomerization.

\section{Catalytic domain (CD)}

The CD of orphan GCs closely resembles that of adenylyl cyclase (AC) type II. The crystal structure of the C2 domain of AC type II was solved (Tesmer et al., 1997; Zhang et al., 1997) and used to generate a model of the CD of bovine GC-E. In the homo-dimer of AC, Lys, Asp and Gln residues, which interact with a purine ring, determine substrate specificity. The Lys residue corresponds to E925 of GC-E (Tesmer et al., 1997). Replacement of E925 by Lys and C995 by Asp in GC-E changes substrate specificity of the mutant from GTP to ATP (Tesmer et al., 1997; Tucker et al., 1998). Similar results were obtained for mutagenesis studies involving soluble GC and AC (Sunahara et al., 1998).

The catalytic site is located in the cleft between two domains in the homo-dimer of CDs in the current model of GC (Fig. 1D). Thus, each domain contributes in forming two catalytic sites, where an Asp from one domain is a general base in the cyclization reaction, and the transition state is stabilized by a conserved Asn-Arg pair on the other domain (Hurley, 1998; Tucker et al., 1998). An essential cofactor of GTP cyclization is a divalent metal ion $\left(\mathrm{Mg}^{2+}\right.$ or $\left.\mathrm{Mn}^{2+}\right)$, which forms a complex with GTP, where the metal ion is coordinated to the $\beta$ - and $\gamma$-phosphate of this nucleotide as shown for GC-E (Koch et al., 1990).

\section{Carboxy terminal tail}

Similar to GC-C, sensory GCs have a 40-60 amino acid-long extended C-terminal regions. This C-terminal extension is not found in NPRs. The C-terminal tail may be involved in the interaction with cytoskeletal proteins (Lucas et al., 2000). In photoreceptor cells, tubulin associates tightly with GC-E (Schrem et al., 1999). In addition, IKEPP (intestinal and kidney-enriched PDZ protein), associates with the C-terminal region of GC-C (Scott et $a l .$, 2002). The association with IKEPP significantly inhibits STa-mediated activation of GC-C. Extension of the C-terminus of the GC-E by GCAP1 eliminated enzyme activity (Sokal et al., 2002), suggesting a unique function of the short C-terminal region in photoreceptor GCs. Structural studies will determine the role of this region on the mechanistic level.

\section{REGULATION OF PHOTORECEPTOR GUANYLATE CYCLASES}

\section{Regulation of GCs by GCAPs}

In the mammalian retina, three GCAPs (GCAP1, GCAP2 and GCAP3) have been identified (Gorczyca et al., 1994; 1995; Palczewski et al., 1994; Dizhoor et al., 1995; Haeseleer et al., 1999; Kobialka \& Gorczyca, 2000; Imanishi et al., 2002; Gorczyca et al., 2003) that regulate the activity of photoreceptor GCs in $\mathrm{Ca}^{2+}$-dependent manners. GCAPs belong to the family of recoverin-like proteins with limited homology to CaM, and they are myristoylated at the N-terminus (Palczewski et al., 1994). Members of the family have similar molecular masses and three functional EF-hand motifs for $\mathrm{Ca}^{2+}$ coordination. Sev- 
eral extensive reviews cover the properties of this subfamily and photoreceptor GCs (Polans et al., 1996; 1997; Pugh et al., 1999; Dizhoor, 2000; Palczewski et al., 2000; Koch et al., 2002), therefore, in the remaining part of this review, we will focus on the selected aspects the function/structure relationship of GCAPs.

The structure of unmyristoylated GCAP2 in the $\mathrm{Ca}^{2+}$-bound form has been revealed by NMR (Ames et al., 1999). The overall shape of the molecule resembles that of recoverin (Flaherty et al., 1993; Ames et al., 1994), neurocalcin (Vijay-Kumar \& Kumar, 1999), and frequenin (Bourne et al., 2001). The RMSD of the main chain atoms between the GCAP2 structure and recoverin is $2.2 \AA$ and between GCAP2 and neurocalcin is $2.0 \AA$ within the EF-hand motifs.

GCAP2 is a compact protein consisting of two regions separated by a flexible linker (Figs. 4A and 4B, helix 6) (Ames et al., 1999).

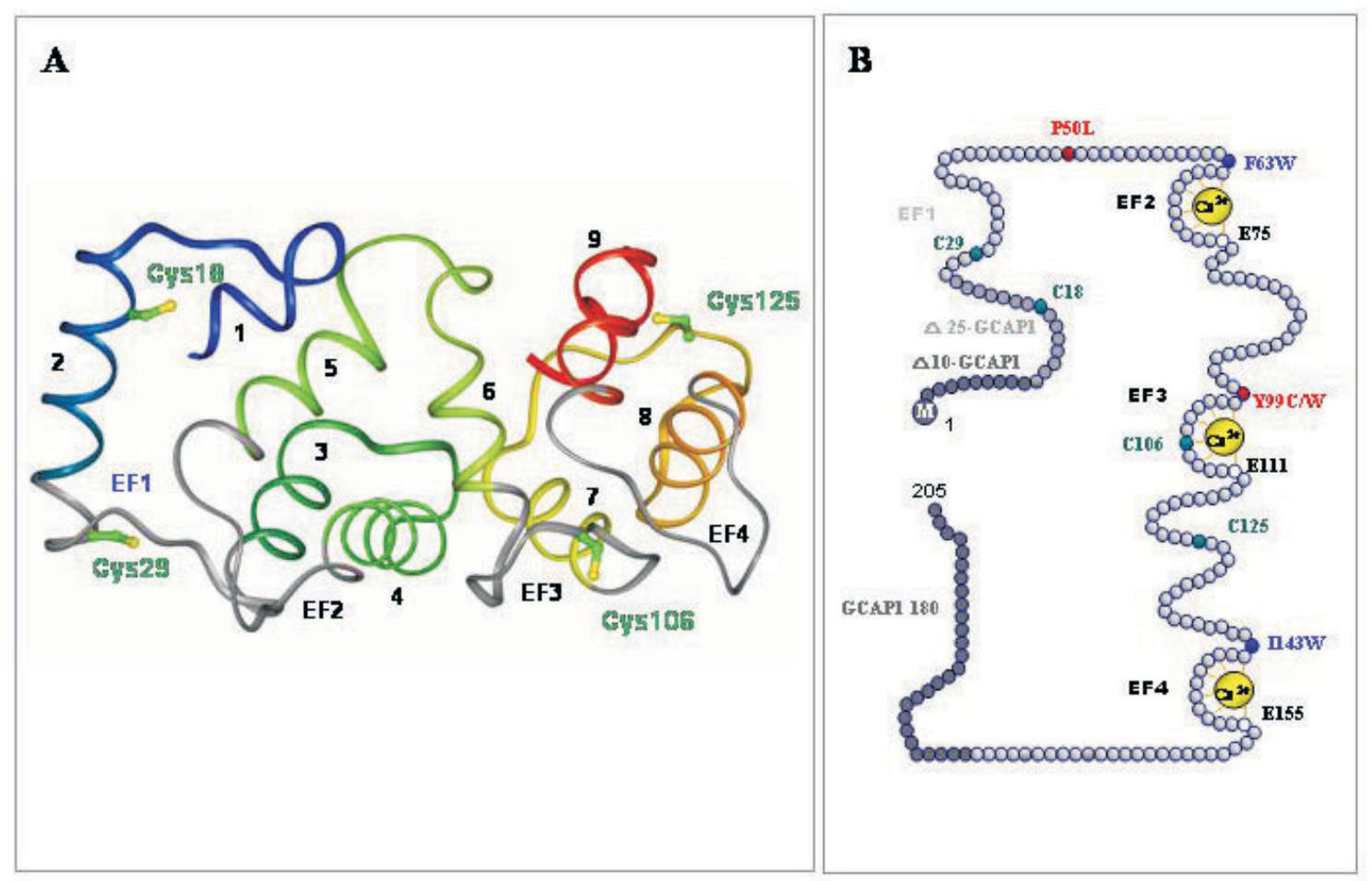

Figure 4. Structure of guanylate cyclase-activating protein 1.

A. A three dimensional model of GCAP1 based on the structure of GCAP2 (Ames et al., 1999). The helices are numbered and the EF-hand motifs are shown in gray. The central helix 6 is bridging two halves of GCAP to form a compact structure. Note that EF-hand 1 is nonfunctional and the model lacks the $\mathrm{N}$-terminal myristoylation group not present in the original structure of GCAP2. Cys residues are marked in the GCAP1 three-dimensional model. This figure is reproduced from (Sokal et al., 2001) with permission from the American Society for Biochemistry and Molecular Biology. B. A model of the primary structure of GCAP1 and its mutants. Tyr and Pro residues mutated to Cys and Leu, respectively that are associated with autosomal dominant come dystrophy are shown in red. The native four Cys residues are represented in green, while hydrophobic residues, present in the front of $\mathrm{Ca}^{2+}$ binding loops, were used to identify conformational changes in GCAP1 (Sokal et al., 1999b), are shown in blue. M indicates myristoylation of GCAP1. Active GCAP1-180 is a deletion mutant lacking the C-terminal region. Further C-terminus truncation renders GCAP1 inactive. Active $\triangle 10$-GCAP1 and inactive $\triangle 25$-GCAP1 are deletion mutants lacking the N-terminal region, thus identifying the minimal essential region of GCAP1 necessary for the stimulation of ROS GC (Otto-Bruc et al., 1997). To disable the $\mathrm{Ca}^{2+}$ binding to EF2-, EF3- and EF4-hand motifs, Glu residues $\mathrm{E}^{75}$, $\mathrm{E}^{111}$ and $\mathrm{E}^{125}$ (residues marked by white circles) were changed to Asp (D). Inactivation of EF-2 maintained $\mathrm{Ca}^{2+}$-sensitivity of GCAP1, while inactivation of EF-hand 3 and EF-hand 4 led to constitutive activity (Rudnicka-Nawrot et al., 1998). 
Similar to CaM, the N- and C-terminal domains contain a pair of EF-hands (Haeseleer et al., 2002), the helix-loop-helix motifs (Fig. $4 \mathrm{~A}$, gray). EF-hand 1 is non-functional due to a lack of amino-acid residues essential for $\mathrm{Ca}^{2+}$ coordination. The linker between the two regions forms a U-shape, bringing together on one side all four EF-hands in a compact tandem array. This structure is different from the arrangement of EF-hand motifs in other CaM-like $\mathrm{Ca}^{2+}$-binding proteins (see for comparison in (Haeseleer et al., 2002)). Within this central region (helix 6), a key Y99 residue plays a critical role in the stabilization of the inactive form. When Y99 is changed in GCAP1, the mutant protein switches to the active conformation (Dizhoor et al., 1998; Payne et al., 1998; Sokal et al., 1998). The high-resolution structures of myristoylated $\mathrm{Ca}^{2+}$-free and -bound forms are critical for further understanding of how the $\mathrm{Ca}^{2+}$ signal is translated into a conformational change within this protein.

In the ROS membranes, GC activity increases in the presence of GCAPs when intracellular $\left[\mathrm{Ca}^{2+}\right]_{\text {free }}$ drops below $100 \mathrm{nM}$ and decreases when $\left[\mathrm{Ca}^{2+}\right]_{\text {free }}$ is elevated (Gorczyca et al., 1994; 1995; Palczewski et al., 1994; Dizhoor et al., 1995; Koch \& Stryer, 1988; Haeseleer et al., 1999; Imanishi et al., 2002) (Fig. 5). Several models of the GCAP-mediated activation of photoreceptor GCs have been proposed (Hurley \& Dizhoor, 2000; Koch, 2002; Koch et al., 2002; Olshevskaya et al., 2002).

Two properties of GC-GCAP appear to be consistent with most of the experimental data. First, GCAPs bind to GCs in a different manner than CaM does with its targets (Haeseleer et al., 2002). Second, the interaction of GCAPs occurs by a multi-point attachment with the ICD of GCs and is stable in all ranges of $\left[\mathrm{Ca}^{2+}\right]$ (Gorczyca et al., 1994). Deletion of the ECD and the TM in GC-E has little effect on the interaction with GCAPs (Duda et al., 1996; Laura et al., 1996; Sokal et al., 2002). The most critical part of GCAP1 for this interaction is the $\mathrm{N}$-terminal region (Palczewski et al., 1994; Otto-Bruc et al., 1997; Krylov et al., 1999; Li et al., 2001). Based on fluorescence methods (Sokal et al., 1999b), proteolytic experiments (Rudnicka-Nawrot et al., 1998), as well as chemical modification and modeling studies (Sokal et al., 2001), we concluded that GCAP1 undergoes $\mathrm{Ca}^{2+}$-dependent reorientation of helices at the interface of its $\mathrm{N}$ - and C-terminal regions. Such a rotation causes exposure of hydrophobic residues around central helix 6 (EF-hand 3 area) that ultimately leads to changes in the cata-

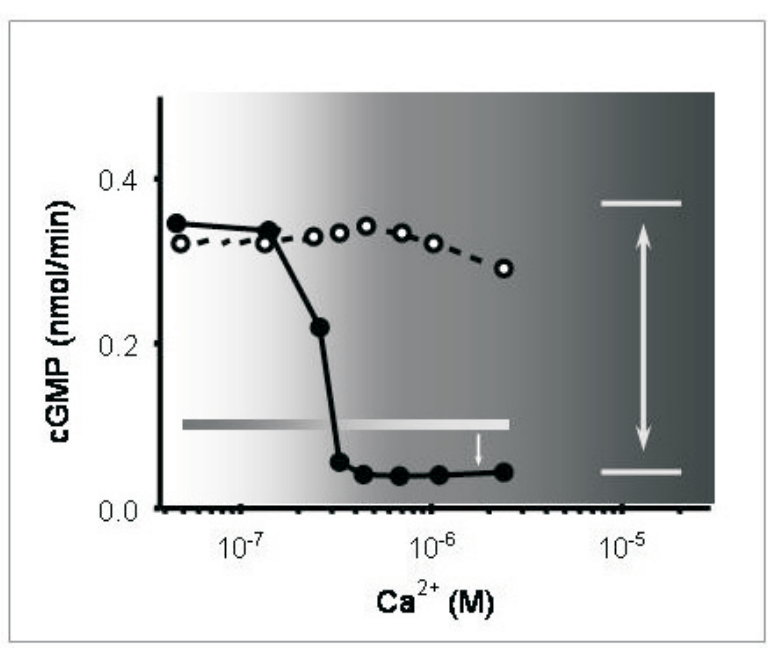

Figure 5. $\mathrm{Ca}^{2+}$-dependent stimulation of GC activity by GCAP1 and $\mathrm{Ca}^{2+}$-insensitivity of its triple mutant with disabled EF-hand loops.

ROS GC activity was reconstituted with GCAP1 (closed circles) or GCAP1-E75DE111DE155D mutant (open circles). Note that the mutant with disabled $\mathrm{Ca}^{2+}$ coordination is constitutively active in the tested range of $\left[\mathrm{Ca}^{2+}\right]$. The shaded background shows the physiological range of $\mathrm{Ca}^{2+}$ changes in photoreceptor cells. The horizontal shaded box indicates the level of the basal cyclase activity and the double arrow indicates difference in activities between the mutant and GCAP1 as a function of $\left[\mathrm{Ca}^{2+}\right]_{\text {free }}$, while the single arrow shows the difference in the level of suppression of basal activity by $\mathrm{Ca}^{2+}$-bound GCAP1.

lytic site of photoreceptors GCs (Sokal et al., 1999b; 2001). GCAPs can modulate the catalytic activity of GC by lowering the activation energy of the GC-GTP transition state (Sokal 
et al., 1999a). Based on the crystal structure of the $\mathrm{C} 2$ domain of $\mathrm{AC}$, a contact region that is critical for the stimulation by $\mathrm{G}_{\mathrm{s}} \alpha$ was identified (Skiba \& Hamm, 1998). In GC-E as in $\mathrm{AC}$, a corresponding region is likely to form a loop between $\alpha$-helix 3 and $\beta$-strand 4 . When this region was replaced by the corresponding sequence of GCAP-insensitive GC-A, GCAPs did not stimulate the mutant (Sokal et al., 1999a). In contrast to recoverin (Zozulya \& Stryer, 1992; Ames et al., 1997), it appears that GCAPs do not undergo the so called $\mathrm{Ca}^{2+}$-myristoyl switch (Hughes et al., 1995). However, removal of the N-terminal part (Fig. 4B) changed the $\mathrm{Ca}^{2+}$ inhibition profile of GCAP1 (Otto-Bruc et al., 1997). This property is different for GCAP2, which is less affected by the mutation, deletion, or lack of a myristoylated group in the $\mathrm{N}$-terminal region (Olshevskaya et al., 1997; Hwang \& Koch, 2002a; Hwang \& Koch, 2002b).

\section{S100 and GC}

Sitaramayya and colleagues discovered that GC-E is also activated by $\mathrm{S} 100$ protein (Margulis et al., 1996) (reviewed in Sitaramayya et al., 2000). The physiological significance of this regulation awaits confirmation in vivo.

\section{Phosphorylation/dephosphorylation}

First, it was shown that cyclic-AMP-dependent protein kinase has an inhibitory effect on GC activity in rat cerebellum extracts (Kumakura et al., 1978) and it was attributed to cyclase phosphorylation (Zwiller et al., 1981). GC-A and -B are constitutively phosphorylated in heterologous expression systems (reviewed see Potter \& Hunter, 2001). Because phosphorylation is essential for the receptor activity, the phosphate group(s) may have a role in the catalytic process or stabilize the active conformation of the enzyme. $\mathrm{Ser}^{497}, \mathrm{Thr}^{500}, \mathrm{Ser}^{502}, \mathrm{Ser}^{506}, \mathrm{Ser}^{510}$, and $\mathrm{Thr}^{513}$ residues, and $\mathrm{Ser}^{513}$, Thr ${ }^{516}, \mathrm{Ser}^{518}$,
$\mathrm{Ser}^{523}$, and $\mathrm{Ser}^{526}$ were identified as the major phosphorylation sites for GC-A and GC-B, respectively (Potter \& Hunter, 1998a; 1998b; 1999) (Fig. 3). These residues are located within a 17-amino acid stretch of the KHD. Dephosphorylation of only a subset of these sites is proposed to be responsible for the desensitization of GCs (reviewed Potter \& Hunter, 2001). It is critical to correlate the phosphorylation/dephosphorylation of these sites and to identify physiologically relevant protein kinases and phosphatases in selected tissues, rather than when the GC is overexpressed in the heterologous system. The basic properties of phosphatases involved in this process have been described (Bryan \& Potter, 2002). The C-terminal fragment of GC-C contains a protein kinase $\mathrm{C}$ phosphorylation site, and GCs without C-terminal tail lose the ability to respond to ligand (Wada et al., 1996; Deshmane et al., 1997).

Studies on kinases that phosphorylated photoreceptor GCs are even less advanced. In addition to the mentioned work on autophosphorylation of GC-E (Aparicio \& Applebury, 1996), GC-E appears to be modulated by protein kinase $\mathrm{A}$ and $\mathrm{C}$ (Wolbring \& Schnetkamp, 1995). Advanced protein chemistry on photoreceptor GCs is needed for in vitro analysis of post-translational modifications to identification of changes that take place in photoreceptor GCs in vivo upon light stimulation.

\section{DISEASES LINKED TO DEFECTS IN PHOTORECEPTOR GUANYLATE CYCLASE-E AND GUANYLATE CYCLASE-ACTIVATING PROTEIN 1}

The link between mutations in photoreceptor GC and GCAP is outside of the scope of this review. Briefly, mutations within the GC-E gene are responsible for Leber's congenital amaurosis type 1 (LCA1) and specific cone-rod dystrophy type 6 (CRD or CORD6) (Perrault et al., 1996; 1998) (reviewed in 
Duda \& Koch, 2002; Newbold et al., 2002; Perrault et al., 1996). So far, no disease causing mutation has been found in the second photoreceptor specific GC-F. Mutations in GCAP1 are associated with autosomal dominant cone dystrophy (Payne et al., 1998) and are reviewed extensively elsewhere (Palczewski et al., 2000; Sokal et al., 2000; Newbold et al., 2002). So far, no mutation causing disease has been identified in the GCAP2 gene (Payne et al., 1999).

\section{FUNCTION OF PHOTORECEPTOR GUANYLATE CYCLASES AND GUANYLATE CYCLASE-ACTIVATING PROTEINS AS REVEALED BY GENETIC APPROACHES}

The function of GCAPs and GCs becomes clearly delineated from the analysis of transgenic animals and phenotypes of human retinal diseases related to mutations of GCAP/ GC. GC-E is not essential for photoreceptor development, but in the $\underline{\mathrm{rd}}$ (retina degeneration) chicken model for human Leber's congenital amaurosis (Perrault et al., 1999), the absence of GC-E prevents phototransduction and affects survival of rods and cones, similar to the human phenotype (Semple-Rowland et al., 1998). In mice, disruption of the GC-E gene leads to cone-specific dystrophy, underscoring the species differences in GCAP/GC system (Yang et al., 1999). Mouse photoreceptors with a disrupted GCAP1/GCAP2 gene array showed no $\mathrm{Ca}^{2+}$ dependent regulation of GC (Mendez et al., 2001). The lack of $\mathrm{Ca}^{2+}$ sensitivity of GC activity indicates that $\mathrm{S} 100$ proteins have no role in regulation of GC in ROS. GCAP1 and not GCAP2 rescued normal photoreceptor responses in mice of the GCAP1/GCAP2 null background (Howes et al., 2002; Pennesi et al., 2003). Constitutive activation of GCAP1 causes autosomal dominant cone dystrophy (Dizhoor et al., 1998; Payne et al., 1998; Sokal et al., 1998; 2000). It is unclear why rods are not affected. Other combinations of GCs and GCAPs are awaiting biochemical and physiological evaluations.

In summary, each protein that is involved in phototransduction is related to every other protein in more ways than is currently understood. Unraveling these complex interactions for the key components of phototransduction, $\mathrm{GC}$ and GCAPs, is the next challenge. Although the understanding of the GC-GCAP systems is quite advanced, clearly missed are structural studies that would allow us to verify several hypotheses at the molecular level. A new, promising approach is to employ soluble fusion forms of GCs complexed with GCAPs for structural studies (Sokal et al., 2002). There is also a need for the high-resolution structure of GCAP1 in $\mathrm{Ca}^{2+}$-bound and free forms to fill the gap in a collection of high-resolution structures of proteins involved in phototransduction (Ridge et al., 2003).

We would like to thank Dr. W. Baehr, Dr. R Stenkamp, Dr. A. Moise, M. Diaz, M. Batten and A. Huang for their comments during manuscript preparation, and Dr. R Stenkamp for preparation of Fig. 1C.

\section{R E F E R E N C E S}

Ames JB, Tanaka T, Stryer L, Ikura M. (1994)

Secondary structure of myristoylated recoverin determined by three-dimensional heteronuclear NMR: implications for the calcium-myristoyl switch. Biochemistry.; 33: 10743-53.

Ames JB, Ishima R, Tanaka T, Gordon JI, Stryer L, Ikura M. (1997) Molecular mechanics of calcium-myristoyl switches. Nature.; 389: 198-202.

Ames JB, Dizhoor AM, Ikura M, Palczewski K, Stryer L. (1999) Three-dimensional structure of guanylyl cyclase activating protein-2, a calcium-sensitive modulator of photoreceptor guanylyl cyclases. J Biol Chem.; 274: 19329-37. 
Aparicio JG, Applebury ML. (1996) The photoreceptor guanylate cyclase is an autophosphorylating protein kinase. $J$ Biol Chem.; 271: 27083-9.

Arshavsky VY, Lamb TD, Pugh EN, Jr. (2002) $\mathrm{G}$ proteins and phototransduction. Annu Rev Physiol.; 64: 153-87.

Bakre MM, Ghanekar Y, Visweswariah SS. (2000) Homologous desensitization of the human guanylate cyclase $\mathrm{C}$ receptor. Cell-specific regulation of catalytic activity. Eur $J$ Biochem.; 267: 179-87.

Baude EJ, Arora VK, Yu S, Garbers DL, Wedel BJ. (1997) The cloning of a Caenorhabditis elegans guanylyl cyclase and the construction of a ligand-sensitive mammalian/nematode chimeric receptor. J Biol Chem.; 272: 16035-9.

Baylor DA, Burns ME. (1998) Control of rhodopsin activity in vision. Eye.; 12 (Pt 3b): $521-5$.

Bourne Y, Dannenberg J, Pollmann V, Marchot P, Pongs O. (2001) Immunocytochemical localization and crystal structure of human frequenin (neuronal calcium sensor 1). J Biol Chem.; 276: 11949-55.

Bownds D, Brodie AE. (1975) Light-sensitive swelling of isolated frog rod outer segments as an in vitro assay for visual transduction and dark adaptation. $J$ Gen Physiol.; 66: 407-25.

Bryan PM, Potter LR. (2002) The atrial natriuretic peptide receptor (NPR-A/GC-A) is dephosphorylated by distinct microcystin-sensitive and magnesium-dependent protein phosphatases. J Biol Chem.; 277: 16041-7.

Chinkers M, Garbers DL. (1989) The protein kinase domain of the ANP receptor is required for signaling. Science.; 245: 1392-4.

Chinkers M, Wilson EM. (1992) Ligand-independent oligomerization of natriuretic peptide receptors. Identification of heteromeric receptors and a dominant negative mutant. $J$ Biol Chem.; 267: 18589-97.

De Lean A, McNicoll N, Labrecque J. (2003) Natriuretic peptide receptor A activation sta- bilizes a membrane-distal dimer interface. $J$ Biol Chem.; 278: 11159-66.

Deshmane SP, Parkinson SJ, Crupper SS, Robertson DC, Schulz S, Waldman SA. (1997) Cytoplasmic domains mediate the ligand-induced affinity shift of guanylyl cyclase C. Biochemistry.; 36: 12921-9.

Dizhoor AM. (2000) Regulation of cGMP synthesis in photoreceptors: role in signal transduction and congenital diseases of the retina. Cell Signal.; 12: 711-9.

Dizhoor AM, Lowe DG, Olshevskaya EV, Laura RP, Hurley JB. (1994) The human photoreceptor membrane guanylyl cyclase, RetGC, is present in outer segments and is regulated by calcium and a soluble activator. Neuron.; 12: 1345-52.

Dizhoor AM, Olshevskaya EV, Henzel WJ, Wong SC, Stults JT, Ankoudinova I, Hurley JB. (1995) Cloning, sequencing, and expression of a $24-\mathrm{kDa} \mathrm{Ca}{ }^{2+}$-binding protein activating photoreceptor guanylyl cyclase. $J$ Biol Chem.; 270: 25200-6.

Dizhoor AM, Boikov SG, Olshevskaya EV. (1998) Constitutive activation of photoreceptor guanylate cyclase by Y99C mutant of GCAP-1. Possible role in causing human autosomal dominant cone degeneration. J Biol Chem.; 273: 17311-4.

Drewett JG, Garbers DL. (1994) The family of guanylyl cyclase receptors and their ligands. Endocr Rev.; 15: 135-62.

Duda T, Koch KW. (2002) Retinal diseases linked with photoreceptor guanylate cyclase. Mol Cell Biochem.; 230: 129-38.

Duda T, Goraczniak R, Surgucheva I, Rudnicka-Nawrot M, Gorczyca WA, Palczewski K, Sitaramayya A, Baehr W, Sharma RK. (1996) Calcium modulation of bovine photoreceptor guanylate cyclase. Biochemistry.; 35: 8478-82.

Duda T, Koch KW, Venkataraman V, Lange C, Beyermann M, Sharma RK. (2002) $\mathrm{Ca}^{2+}$ sensor S100beta-modulated sites of membrane guanylate cyclase in the photoreceptor-bipolar synapse. EMBO J.; 21: 2547-56. 
Fain GL, Matthews HR, Cornwall MC, Koutalos Y. (2001) Adaptation in vertebrate photoreceptors. Physiol Rev.; 81: 117-51.

Fesenko EE, Kolesnikov SS, Lyubarsky AL. (1985) Induction by cyclic GMP of cationic conductance in plasma membrane of retinal rod outer segment. Nature.; 313: 310-13.

Filipek S, Stenkamp RE, Teller DC, Palczewski K. (2003) G protein-coupled receptor rhodopsin: A prospectus. Annu Rev Physiol.; 65: 851-79.

Flaherty KM, Zozulya S, Stryer L, McKay DB. (1993) Three-dimensional structure of recoverin, a calcium sensor in vision. Cell.; 75: $709-16$.

Frank RN, Buzney SM. (1975) Mechanism and specificity of rhodopsin phosphorylation. Biochemistry.; 14: 5110-7.

Fulle HJ, Vassar R, Foster DC, Yang RB, Axel R, Garbers DL. (1995) A receptor guanylyl cyclase expressed specifically in olfactory sensory neurons. Proc Natl Acad Sci U S A.; 92: 3571-5.

Garbers DL. (1989) Guanylate cyclase, a cell surface receptor. J Biol Chem.; 264: 9103-6.

Gorczyca WA, Gray-Keller MP, Detwiler PB, Palczewski K. (1994) Purification and physiological evaluation of a guanylate cyclase activating protein from retinal rods. Proc Natl Acad Sci U S A.; 91: 4014-8.

Gorczyca WA, Polans AS, Surgucheva IG, Subbaraya I, Baehr W, Palczewski K. (1995) Guanylyl cyclase activating protein A calcium-sensitive regulator of phototransduction. J Biol Chem.; 270: 22029-36.

Gorczyca WA, Kobialka M, Kuropatwa M, Kurowska E. (2003) $\mathrm{Ca}^{2+}$ differently affects hydrophobic properties of guanylyl cyclase-activating proteins. (GCAPs) and recoverin. Acta Biochim Polon.; 50: 367-76.

Haeseleer F, Imanishi Y, Sokal I, Filipek S, Palczewski K. (2002) Calcium-binding proteins: intracellular sensors from the calmodulin superfamily. Biochem Biophys Res Commun.; 290: 615-23.
Haeseleer F, Sokal I, Li N, Pettenati M, Rao N, Bronson D, Wechter R, Baehr W, Palczewski K. (1999) Molecular characterization of a third member of the guanylyl cyclase-activating protein subfamily. $J$ Biol Chem.; 274: 6526-35.

He X, Chow D, Martick MM, Garcia KC. (2001) Allosteric activation of a spring-loaded natriuretic peptide receptor dimer by hormone. Science.; 293: 1657-62.

Heck M, Hofmann KP. (2001) Maximal rate and nucleotide dependence of rhodopsin-catalyzed transducin activation: initial rate analysis based on a double displacement mechanism. J Biol Chem.; 276: 10000-9.

Howes KA, Pennesi ME, Sokal I, Church-Kopish J, Schmidt B, Margolis D, Frederick JM, Rieke F, Palczewski K, Wu SM, Detwiler PB, Baehr W. (2002) GCAP1 rescues rod photoreceptor response in GCAP1/GCAP2 knockout mice. EMBO J.; 21: 1545-54.

Hughes RE, Brzovic PS, Klevit RE, Hurley JB. (1995) Calcium-dependent solvation of the myristoyl group of recoverin. Biochemistry.; 34: $11410-6$.

Hurley JH. (1998) The adenylyl and guanylyl cyclase superfamily. Curr Opin Struct Biol.; 8: $770-7$.

Hurley JB, Dizhoor AM. (2000) Heterologous expression and assays for photoreceptor guanylyl cyclases and guanylyl cyclase activating proteins. Methods Enzymol.; 315: 708-17.

Hwang JY, Koch KW. (2002a) Calcium- and myristoyl-dependent properties of guanylate cyclase-activating protein-1 and protein-2. Biochemistry.; 41: 13021-8.

Hwang JY, Koch KW. (2002b) The myristoylation of the neuronal $\mathrm{Ca}^{2+}$-sensors guanylate cyclase-activating protein 1 and 2 . Biochim Biophys Acta.; 1600: 111-7.

Imanishi Y, Li N, Sokal I, Sowa ME, Lichtarge O, Wensel TG, Saperstein DA, Baehr W, Palczewski K. (2002) Characterization of retinal guanylate cyclase-activating protein 3 . (GCAP3) from zebrafish to man. Eur $J$ Neurosci.; 15: 63-78. 
Juilfs DM, Fulle HJ, Zhao AZ, Houslay MD, Garbers DL, Beavo, JA. (1997) A subset of olfactory neurons that selectively express cGMP-stimulated phosphodiesterase (PDE2) and guanylyl cyclase-D define a unique olfactory signal transduction pathway. Proc Natl Acad Sci U S A.; 94: 3388-95.

Kobialka M, Gorczyca WA. (2000) Particulate guanylyl cyclases: multiple mechanisms of activation. Acta Biochim Polon.; 47: 517-28.

Koch KW. (2002) Target recognition of guanylate cyclase by guanylate cyclase-activating proteins. Adv Exp Med Biol.; 514: 349-60.

Koch KW, Duda T, Sharma RK. (2002) Photoreceptor specific guanylate cyclases in vertebrate phototransduction. $\mathrm{Mol}$ Cell Biochem.; 230: 97-106.

Koch KW, Eckstein F, Stryer L. (1990) Stereochemical course of the reaction catalyzed by guanylate cyclase from bovine retinal rod outer segments. J Biol Chem.; 265: 9659-63.

Koch KW, Stecher P, Kellner R. (1994) Bovine retinal rod guanyl cyclase represents a new $\mathrm{N}$-glycosylated subtype of membrane-bound guanyl cyclases. Eur J Biochem.; 222: 589-95.

Koch KW, Stryer L. (1988) Highly cooperative feedback control of retinal rod guanylate cyclase by calcium ions. Nature.; 334: 64-6.

Kraulis PJ. (1991) J Appl Crystallography.; 946-50.

Krylov DM, Niemi GA, Dizhoor AM, Hurley JB. (1999) Mapping sites in guanylyl cyclase activating protein- 1 required for regulation of photoreceptor membrane guanylyl cyclases. J Biol Chem.; 274: 10833-9.

Kuhn H, Bader S. (1976) The rate of rhodopsin phosphorylation in isolated rentinas of frog and cattle. Biochim Biophys Acta.; 428: 13-8.

Kuhn H, Dreyer WJ. (1972) Light dependent phosphorylation of rhodopsin by ATP. FEBS Lett.; 20: 1-6.
Kuhn H, Hall SW, Wilden U. (1984) Light-induced binding of $48-\mathrm{kDa}$ protein to photoreceptor membranes is highly enhanced by phosphorylation of rhodopsin. FEBS Lett.; 176: 473-8.

Kumakura K, Battaini F, Hofmann M, Spano PF, Trabucchi M. (1978) Inhibitory effects of cyclic-AMP dependent protein kinase on guanylate cyclase activity in rat cerebellum. FEBS Lett.; 93: 231-4.

Laura RP, Dizhoor AM, Hurley JB. (1996) The membrane guanylyl cyclase, retinal guanylyl cyclase- 1 , is activated through its intracellular domain. $J$ Biol Chem.; 271: 11646-51.

Leskov IB, Klenchin VA, Handy JW, Whitlock GG, Govardovskii VI, Bownds MD, Lamb TD, Pugh EN, Jr, Arshavsky VY. (2000) The gain of rod phototransduction: reconciliation of biochemical and electrophysiological measurements. Neuron.; 27: 525-37.

Li N, Sokal I, Bronson JD, Palczewski K, Baehr W. (2001) Identification of functional regions of guanylate cyclase-activating protein 1 . (GCAP1) using GCAP1/GCIP chimeras. Biol Chem.; 382: 1179-88.

Lolley RN, Racz E. (1982) Calcium modulation of cyclic GMP synthesis in rat visual cells. Vision Res.; 22: 1481-6.

Lowe DG, Dizhoor AM, Liu K, Gu Q, Spencer M, Laura R, Lu L, Hurley JB. (1995) Cloning and expression of a second photoreceptor-specific membrane retina guanylyl cyclase (RetGC), RetGC-2. Proc Natl Acad Sci U S A.; 92: 5535-9.

Lucas KA, Pitari GM, Kazerounian S, Ruiz-Stewart I, Park J, Schulz S, Chepenik KP, Waldman SA. (2000) Guanylyl cyclases and signaling by cyclic GMP. Pharmacol Rev.; 52: 375-414.

Maeda T, Imanishi Y, Palczewski K. (2003) Rhodopsin phosphorylation: 30 years later. Prog Retin Eye Res.; 22: 417-34.

Marchese A, Nguyen T, Malik P, Xu S, Cheng R, Xie Z, Heng HH, George SR, Kolakowski LF, Jr, O’Dowd BF. (1998) Cloning genes en- 
coding receptors related to chemoattractant receptors. Genomics.; 50: 281-6.

Margulis A, Goraczniak RM, Duda T, Sharma RK, Sitaramayya A. (1993) Structural and biochemical identity of retinal rod outer segment membrane guanylate cyclase. Biochem Biophys Res Commun.; 194: 855-61.

Margulis A, Pozdnyakov N, Sitaramayya A. (1996) Activation of bovine photoreceptor guanylate cyclase by S100 proteins. Biochem Biophys Res Commun.; 218: 243-7.

Mendez A, Burns ME, Sokal I, Dizhoor AM, Baehr W, Palczewski K, Baylor DA, Chen J. (2001) Role of guanylate cyclase-activating proteins (GCAPs) in setting the flash sensitivity of rod photoreceptors. Proc Natl Acad Sci U S A.; 98: 9948-53.

Merritt EA, Bacon JD. (1997) Raster3D photorealistic molecular graphics". Methods in Enzymology.; 277: 505-24.

Miller JA, Brodie AE, Bownds MD. (1975) Light-activated rhodopsin phosphorylation may control light sensitivity in isolated rod outer segments. FEBS Lett.; 59: 20-3.

Misono KS. (2000) Atrial natriuretic factor binding to its receptor is dependent on chloride concentration: A possible feedback-control mechanism in renal salt regulation. Circ Res.; 86: 1135-9.

Newbold RJ, Deery EC, Payne AM, Wilkie SE, Hunt DM, Warren MJ. (2002) Guanylate cyclase activating proteins, guanylate cyclase and disease. Adv Exp Med Biol.; 514: 411-38.

Okada T, Ernst OP, Palczewski K, Hofmann KP. (2001) Activation of rhodopsin: new insights from structural and biochemical studies. Trends Biochem Sci.; 26: 318-24.

Olshevskaya EV, Hughes, RE, Hurley JB, Dizhoor AM. (1997) Calcium binding, but not a calcium-myristoyl switch, controls the ability of guanylyl cyclase-activating protein GCAP-2 to regulate photoreceptor guanylyl cyclase. J Biol Chem.; 272: 14327-33.

Olshevskaya EV, Ennilov AN, Dizhoor AM. (2002) Factors that affect regulation of cGMP synthesis in vertebrate photoreceptors and their genetic link to human retinal degeneration. Mol Cell Biochem.; 230: 139-47.

Otto-Bruc A, Buczylko J, Surgucheva I, Subbaraya I, Rudnicka-Nawrot M, Crabb JW, Arendt A, Hargrave PA, Baehr W, Palczewski K. (1997) Functional reconstitution of photoreceptor guanylate cyclase with native and mutant forms of guanylate cyclase-activating protein 1. Biochemistry.; 36: 4295-302.

Palczewski K. (1997) GTP-binding-protein-coupled receptor kinases - two mechanistic models. Eur J Biochem.; 248: 261-9.

Palczewski K, Benovic JL. (1991) G-protein-coupled receptor kinases. Trends Biochem Sci.; 16: $387-91$.

Palczewski K, Subbaraya I, Gorczyca WA, Helekar BS, Ruiz CC, Ohguro H, Huang J, Zhao X, Crabb JW, Johnson RS, et al. (1994) Molecular cloning and characterization of retinal photoreceptor guanylyl cyclase-activating protein. Neuron.; 13: 395-404.

Palczewski K, Polans AS, Baehr W, Ames JB. (2000) $\mathrm{Ca}^{2+}$-binding proteins in the retina: structure, function, and the etiology of human visual diseases. Bioessays.; 22: 337-50.

Payne AM, Downes SM, Bessant DA, Plant C, Moore T, Bird AC, Bhattacharya SS. (1999) Genetic analysis of the guanylate cyclase activator 1B. (GUCA1B) gene in patients with autosomal dominant retinal dystrophies. $J$ Med Genet.; 36: 691-3.

Payne AM, Downes SM, Bessant DA, Taylor R, Holder GE, Warren MJ, Bird AC, Bhattacharya SS. (1998) A mutation in guanylate cyclase activator 1A (GUCA1A) in an autosomal dominant cone dystrophy pedigree mapping to a new locus on chromosome 6p211. Hum Mol Genet.; 7: 273-7.

Pennesi ME, Howes KA, Baehr W, Wu SM. (2003) Guanylate cyclase-activating protein. (GCAP) 1 rescues cone recovery kinetics in GCAP1/GCAP2 knockout mice. Proc Natl Acad Sci U S A.; 100: 6783-8.

Perrault I, Rozet JM, Calvas P, Gerber S, Camuzat A, Dollfus H, Chatelin S, Souied E, Ghazi I, Leowski C, Bonnemaison M, Le 
Paslier D, Frezal J, Dufier JL, Pittler S, Munnich A, Kaplan J. (1996) Retinal-specific guanylate cyclase gene mutations in Leber's congenital amaurosis. Nat Genet.; 14: 461-4.

Perrault I, Rozet JM, Gerber S, Kelsell RE, Souied E, Cabot A, Hunt DM, Munnich A, Kaplan J. (1998) A retGC-1 mutation in autosomal dominant cone-rod dystrophy. Am J Hum Genet.; 63: 651-4.

Perrault I, Rozet JM, Gerber S, Ghazi I, Leowski C, Ducroq D, Souied E, Dufier JL, Munnich A, Kaplan J. (1999) Leber congenital amaurosis. Mol Genet Metab.; 68: 200-8.

Polans A, Baehr W, Palczewski K. (1996) Turned on by $\mathrm{Ca}^{2+}$ ! The physiology and pathology of $\mathrm{Ca}^{2+}$-binding proteins in the retina. Trends Neurosci.; 19: 547-54.

Potter LR. (1998) Phosphorylation-dependent regulation of the guanylyl cyclase-linked natriuretic peptide receptor B: dephosphorylation is a mechanism of desensitization. Biochemistry.; 37: 2422-9.

Potter LR, Hunter T. (1998a) Identification and characterization of the major phosphorylation sites of the B-type natriuretic peptide receptor. J Biol Chem.; 273: 15533-9.

Potter LR, Hunter T. (1998b) Phosphorylation of the kinase homology domain is essential for activation of the A-type natriuretic peptide receptor. Mol Cell Biol.; 18: 2164-72.

Potter LR, Hunter T. (1999) A constitutively "phosphorylated" guanylyl cyclase-linked atrial natriuretic peptide receptor mutant is resistant to desensitization. Mol Biol Cell.; 10: $1811-20$.

Potter LR, Hunter T. (2001) Guanylyl cyclase-linked natriuretic peptide receptors: structure and regulation. $J$ Biol Chem.; 276: 6057-60.

Pugh EN Jr, Duda T, Sitaramayya A, Sharma RK. (1997) Photoreceptor guanylate cyclases: a review. Biosci Rep.; 17: 429-73.

Pugh EN Jr, Nikonov S, Lamb TD. (1999) Molecular mechanisms of vertebrate photoreceptor light adaptation. Curr Opin Neurobiol.; 9: 410-8.
Ridge KD, Abdulaev NG, Sousa M, Palczewski K. (2003) Phototransduction: crystal clear. Trends Biochem Sci.; 28: 479-87.

Rondeau JJ, McNicoll N, Gagnon J, Bouchard N, Ong H, De Lean A. (1995) Stoichiometry of the atrial natriuretic factor-R 1 receptor complex in the bovine zona glomerulosa. Biochemistry.; 34: 2130-6.

Rudnicka-Nawrot M, Surgucheva I, Hulmes JD, Haeseleer F, Sokal I, Crabb JW, Baehr W, Palczewski K. (1998) Changes in biological activity and folding of guanylate cyclase-activating protein 1 as a function of calcium. Biochemistry.; 37: 248-57.

Sayle RA, Milner-White EJ. (1995) RASMOL: biomolecular graphics for all. Trends Biochem Sci.; 20: 374.

Schrem A, Lange C, Beyermann M, Koch KW. (1999) Identification of a domain in guanylyl cyclase-activating protein 1 that interacts with a complex of guanylyl cyclase and tubulin in photoreceptors. $J$ Biol Chem.; 274: 6244-9.

Schulz S, Wedel BJ, Matthews A, Garbers DL. (1998) The cloning and expression of a new guanylyl cyclase orphan receptor. $J$ Biol Chem.; 273: 1032-7.

Scott RO, Thelin WR, Milgram SL. (2002) A novel PDZ protein regulates the activity of guanylyl cyclase $\mathrm{C}$, the heat-stable enterotoxin receptor. $J$ Biol Chem.; 277: 22934-41.

Sefton BM. (1989) Protein kinases. Cancer Cells.; 1: 64-5.

Semple-Rowland SL, Lee NR, Van Hooser JP, Palczewski K, Baehr W. (1998) A null mutation in the photoreceptor guanylate cyclase gene causes the retinal degeneration chicken phenotype. Proc Natl Acad Sci U S A.; 95: 1271-6.

Shyjan AW, de Sauvage FJ, Gillett NA, Goeddel DV, Lowe DG. (1992) Molecular cloning of a retina-specific membrane guanylyl cyclase. Neuron.; 9: 727-37.

Singh S, Lowe DG, Thorpe DS, Rodriguez H, Kuang WJ, Dangott LJ, Chinkers M, Goeddel DV, Garbers DL. (1988) Membrane 
guanylate cyclase is a cell-surface receptor with homology to protein kinases. Nature; 334: 708-12.

Sitaramayya A, Pozdnyakov N, Margulis A, Yoshida A. (2000) Calcium-dependent activation of membrane guanylate cyclase by S100 proteins. Methods Enzymol.; 315: 730-42.

Skiba NP, Hamm HE. (1998) How Gs $\alpha$ activates adenylyl cyclase. Nat Struct Biol.; 5: 88-92.

Soderling SH, Beavo JA. (2000) Regulation of cAMP and cGMP signaling: new phosphodiesterases and new functions. Curr Opin Cell Biol.; 12: 174-9.

Sokal I, Alekseev A, Baehr W, Haeseleer F, Palczewski K. (2002) Soluble fusion proteins between single transmembrane photoreceptor guanylyl cyclases and their activators. Biochemistry.; 41: 251-7.

Sokal I, Haeseleer F, Arendt A, Adman ET, Hargrave PA, Palczewski K. (1999a) Identification of a guanylyl cyclase-activating protein-binding site within the catalytic domain of retinal guanylyl cyclase 1 . Biochemistry.; 38: 1387-93.

Sokal I, Li N, Klug CS, Filipek S, Hubbell WL, Baehr W, Palczewski K. (2001) Calcium-sensitive regions of GCAP1 as observed by chemical modifications, fluorescence, and EPR spectroscopies. J Biol Chem.; 276: 43361-73.

Sokal I, Li N, Surgucheva I, Warren MJ, Payne AM, Bhattacharya SS, Baehr W, Palczewski K. (1998) GCAP1. (Y99C) mutant is constitutively active in autosomal dominant cone dystrophy. Mol Cell.; 2: 129-33.

Sokal I, Li N, Verlinde CL, Haeseleer F, Baehr W, Palczewski K. (2000) $\mathrm{Ca}^{2+}$-binding proteins in the retina: from discovery to etiology of human disease(1). Biochim Biophys Acta.; 1498: $233-51$.

Sokal I, Otto-Bruc AE, Surgucheva I, Verlinde CL, Wang CK, Baehr W, Palczewski K. (1999b) Conformational changes in guanylyl cyclase-activating protein 1 (GCAP1) and its tryptophan mutants as a function of calcium concentration. J Biol Chem.; 274: 19829-37.
Stryer L. (1983) Transducin and the cyclic GMP phosphodiesterase: amplifier proteins in vision. Cold Spring Harb Symp Quant Biol.; 48 Pt 2: 841-52.

Sunahara RK, Beuve A, Tesmer JJ, Sprang SR, Garbers DL, Gilman AG. (1998) Exchange of substrate and inhibitor specificities between adenylyl and guanylyl cyclases. J Biol Chem.; 273: 16332-8.

Tesmer JJ, Sunahara RK, Gilman AG, Sprang SR. (1997) Crystal structure of the catalytic domains of adenylyl cyclase in a complex with GsalphaGTPgammaS. Science.; 278: 1907-16.

Thompson DK, Garbers DL. (1995) Dominant negative mutations of the guanylyl cyclase-A receptor. Extracellular domain deletion and catalytic domain point mutations. $J$ Biol Chem.; 270: 425-30.

Thorpe DS, Niu S, Morkin E. (1991) Overexpression of dimeric guanylyl cyclase cores of an atrial natriuretic peptide receptor. Biochem Biophys Res Commun.; 180: 538-44.

Tucker CL, Hurley JH, Miller TR, Hurley JB. (1998) Two amino acid substitutions convert a guanylyl cyclase, RetGC-1, into an adenylyl cyclase. Proc Natl Acad Sci U S A.; 95: 5993-7.

van den Akker F, Zhang X, Miyagi M, Huo X, Misono KS, Yee VC. (2000) Structure of the dimerized hormone-binding domain of a guanylyl-cyclase-coupled receptor. Nature.; 406: $101-4$.

Venkataraman V, Nagele R, Duda T, Sharma RK. (2000) Rod outer segment membrane guanylate cyclase type 1-linked stimulatory and inhibitory calcium signaling systems in the pineal gland: biochemical, molecular, and immunohistochemical evidence. Biochemistry.; 39: 6042-52.

Vijay-Kumar S, Kumar VD. (1999) Crystal structure of recombinant bovine neurocalcin. Nat Struct Biol.; 6: 80-8.

Wada A, Hasegawa M, Matsumoto K, Niidome T, Kawano Y, Hidaka Y, Padilla PI, Kurazono H, Shimonishi Y, Hirayama T. 
(1996) The significance of Ser1029 of the heat-stable enterotoxin receptor. (STaR): relation of STa-mediated guanylyl cyclase activation and signaling by phorbol myristate acetate. FEBS Lett.; 384: 75-7.

Wilden U, Hall SW, Kuhn H. (1986)

Phosphodiesterase activation by photoexcited rhodopsin is quenched when rhodopsin is phosphorylated and binds the intrinsic 48-kDa protein of rod outer segments. Proc Natl Acad Sci U S A.; 83: 1174-8.

Wilson EM, Chinkers M. (1995) Identification of sequences mediating guanylyl cyclase dimerization. Biochemistry.; 34: 4696-701.

Wolbring G, Schnetkamp PP. (1995) Activation by PKC of the $\mathrm{Ca}^{2+}$-sensitive guanylyl cyclase in bovine retinal rod outer segments measured with an optical assay. Biochemistry.; 34: 4689-95.

Wong SK, Garbers, DL. (1992) Receptor guanylyl cyclases. J Clin Invest.; 90: 299-305.

Yang RB, Foster DC, Garbers DL, Fulle HJ. (1995) Two membrane forms of guanylyl cyclase found in the eye. Proc Natl Acad Sci $U S$ A.; 92: 602-6.

Yang RB, Garbers DL. (1997) Two eye guanylyl cyclases are expressed in the same photoreceptor cells and form homomers in preference to heteromers. J Biol Chem.; 272: $13738-42$.

Yang RB, Robinson SW, Xiong WH, Yau KW, Birch DG, Garbers DL. (1999) Disruption of a retinal guanylyl cyclase gene leads to cone-specific dystrophy and paradoxical rod behavior. J Neurosci.; 19: 5889-97.

Yau KW, Baylor DA. (1989) Cyclic GMP-activated conductance of retinal photoreceptor cells. Annu Rev Neurosci.; 12: 289-327.

Yu S, Avery L, Baude E, Garbers DL. (1997) Guanylyl cyclase expression in specific sensory neurons: a new family of chemosensory receptors. Proc Natl Acad Sci U S A.; 94: 3384-7.

Zhang G, Liu Y, Ruoho AE, Hurley JH. (1997) Structure of the adenylyl cyclase catalytic core. Nature.; 386: 247-53.

Zozulya S, Stryer L. (1992) Calcium-myristoyl protein switch. Proc Natl Acad Sci U S A.; 89: $11569-73$.

Zwiller J, Revel MO, Basset P. (1981) Evidence for phosphorylation of rat brain guanylate cyclase by cyclic AMP-dependent protein kinase. Biochem Biophys Res Commun.; 101: 1381-7. 